\title{
Recurrent polyploid origins and chloroplast phylogeography in the Arabis holboellii complex (Brassicaceae)
}

\author{
TIMOTHY F. SHARBEL* \& THOMAS MITCHELL-OLDS \\ Max Planck Institut für Chemische Ökologie, Carl Zeiss Promenade 10, 07745 Jena, Germany
}

\begin{abstract}
Arabis holboellii is a North American member of the Brassicaceae that can reproduce via sex or apomixis. Previous studies have shown sexual individuals to be diploid, whilst apomictic individuals can be diploid (and aneuploid) or polyploid (typically 3x). Apomictic individuals can furthermore be facultative (i.e. both sexual and apomictic seed production in a single individual). Using flow cytometry, ploidy variation in 245 accessions of $A$. holboellii and $A$. drummondii from western North America and Greenland has been examined. Additionally, the chloroplast $\operatorname{trn} L$ intron region from each accession was sequenced for phylogenetic analysis of ploidy variation.

Based upon 17 informative single nucleotide and insertion-deletion polymorphisms, we identified seven and 14 chloroplast haplotypes for A. drummondii and A. holboellii, respectively. Six of the haplotypes were found in both species. Ten of the chloroplast haplotypes were characterized by diploid, aneuploid, and triploid individuals, and thus we conclude that polyploidy has repeatedly and independently arisen within the species complex. As triploid individuals, which undergo normal meiosis, can only reproduce through apomixis, this may imply that the phenotype apomixis has also arisen multiple times. Arabis holboellii thus appears to have some predisposition to evolve apomictic reproduction.
\end{abstract}

Keywords: aneuploid, apomixis, Arabis holboelii, chloroplast, haplotype, polyploid.

\section{Introduction}

Apomixis, the asexual propagation of offspring via female function, is a reproductive phenotype which has evolved independently in distantly related taxa (see Bell, 1982; Beukeboom \& Vrijenhoek, 1998). Many apomictic taxa are polyploid, and two types of argument have been put forward to explain the association of these traits (Bell, 1982). On the one hand, polyploidy may be a requirement for apomixis, whereby expression and/or transmission of 'apomixis genes' is facilitated (Suomalainen, 1950; Mogie, 1986; Asker \& Jerling, 1992; Savidan, 2000). Furthermore, duplicated genes in allopolyploid taxa may undergo asynchronous and subsequent autonomous (i.e. apomictic) development (Carman, 1997), a process resulting from differentiated (i.e. allopolyploid) genomes rather than from any specific gene(s). On the other hand, polyploidy may not be essential for the establishment of apomictic reproduction; instead, apomixis may be selectively advantageous in the polyploid over the diploid condi-

*Correspondence. E-mail: sharbel@ice.mpg.de tion (Bell, 1982; Michod, 1995). Hence, diploid apomixis might be possible, although it might represent a shortlived, transitory state (Suomalainen, 1950; Bell, 1982).

Polyploidy in animals is relatively sporadic, with both even/odd-numbered and allo/autopolyploids known, many of which are apomictic (Bell, 1982; Suomalainen, 1950; but see Beukeboom et al. 2000). Polyploidy is more frequent in plants, and is highly correlated with speciation within the angiosperms (Müntzing, 1936; Ramsey \& Schemske, 1998). Even-numbered polyploidy predominates in plants, and of these, sexual forms greatly outnumber apomicts (Ramsey \& Schemske, 1998). Apomictic plants are almost exclusively polyploid, with tetraploidy being most prevalent (Savidan, 2000).

Arabis holboellii is a biennial or perennial member of the North American (including Greenland) Brassicaceae which can reproduce sexually or through diplosporous apomixis (i.e. meiosis is retained, Böcher, 1951). Among plants, A. holboellii is anomalous as both diploid and triploid (a rare polyploid condition in plants, see Ramsey \& Schemske, 1998) apomicts have been described, in addition to facultative apomixis 
(Böcher, 1951). The basic chromosome number (x) of A. holboellii is 7, and polyploidy (typically $3 \mathrm{x}$ ), aneuploidy and B chromosomes (Camacho et al. 2000) are common (Böcher, 1951; Böcher, 1954). This karyotype variability is consistent with other characteristics of apomictic $A$. holboellii, including large numbers of genetically identifiable clones, fixed heterozygosity, and disjunct apomictic populations (Roy \& Rieseberg, 1989; Roy \& Bierzychudek, 1993; Roy, 1993), which together imply multiple independent origins of apomixis (Roy, 1995).

Independent origin of multiple polyploid lineages could imply that $A$. holboellii is predisposed to apomictic development (sensu Mogie, 1992), as it is unlikely that triploidy would be transmitted stably to the offspring of sexual individuals with normal meiosis (the result of unbalanced gamete formation: Bell, 1982; Ramsey \& Schemske, 1998). This study thus focuses on biogeographical patterns of polyploidy in the A. holboellii complex, which also includes the closely related A. drummondii (Rollins, 1941). A subsequent study will examine inheritance of molecular markers in diploid and polyploid lineages in order to identify reproductive mode. Interspecific hybridization has also been proposed as a possible mechanism leading to the evolution of apomixis (Böcher, 1954), and thus the present study includes related members of Arabis (Rollins, 1941).

\section{Materials and methods}

Seeds from single individuals were collected from six Arabis species and Halimolobus perplexa (phylogenetic outgroup, Koch et al., 1999) from multiple sites encompassing 33 geographical areas (Table 1; Fig. 1). Plants from Montana and adjacent parts of Idaho were identified using keys from Dorn (1984). Other identifications were based on Rollins (1941, 1981), and in addition, species identifications were compared to known herbarium specimens. Five to 10 seeds from each collection site were placed on moist filter paper in Petri plates, and vernalized at $5^{\circ} \mathrm{C}$ for $2-3$ weeks. Upon germination, 3-5 seedlings were transferred to pots $(11 \times 11 \times 13 \mathrm{~cm})$ containing sterilized soil and grown in a controlled environmental growth room. Plants were grown in a 12-h L/D cycle under fluorescent lighting (cool white and GrowLux ${ }^{\odot}$ ), with a daily temperature variation from $22^{\circ}$ to $28^{\circ} \mathrm{C}$.

\section{Sequence analysis}

DNA was isolated from the leaf tissue of single individuals using a Nucleon (Amersham Pharmacia Biotech Europe $\mathrm{GmbH}$ ) extraction kit. DNA quality and concentration were assessed by restriction digestion and visualization of $5 \mu \mathrm{L}$ of the product on a $0.7 \%$ TAE-agarose gel. Part of the chloroplast $t R N A-L e u$ $(\operatorname{trn} L)$ intron was PCR amplified from each individual using the oligonucleotides $\operatorname{trn} L f$ (5' CGAAATCGGTAG ACGCTACG $3^{\prime}$ ) and $\operatorname{trnLr}\left(5^{\prime}\right.$ GGGGATAGAGGGACTTGAAC 3'), and amplification products were assessed on agarose gels. Successful amplifications were purified using a QIAGEN PCR purification kit, and the products were sequenced directly using the ABI Prism $^{\mathrm{TM}}$ BigDye Ready Reaction Terminator Cycle Sequencing Kit on an ABI 3700 genetic analyser. Sequences were generated from at least two separate PCR amplifications per individual, and both strands of all fragments were sequenced.

The program SeQMan 3.58 (DNASTAR Inc.) was used to align the sequence data. The program DNASP 3.0 (Rozas \& Rozas, 1999) was used to calculate nucleotide (ð) and haplotype (gene) diversities (Nei, 1987), and Tajima's $D$ statistic (Tajima, 1989) from sequence data. For haplotype diversity calculation, $2 n$ was replaced by $n$ in Nei's (1987) eqns 8.4 and 8.12 (Rozas \& Rozas, 1999). Phylogenetic analyses were performed using PHYLIP (version 3.5c, Felsenstein, 1989) and TREECON (version 1.3b,van de Peer \& de Wachter, 1994).

\section{Ploidy analyses}

Ploidy analyses were performed on a PARTEC CCAII flow cytometer using their High Resolution Type P nuclei extraction and staining kit (PARTEC GmbH). Samples were run in random order. Young leaf tissue from 5-10 individuals per sampling site were combined, and a single preparation and analysis was run on the pooled sample. If multiple peaks were observed in this pooled sample, every individual was reanalysed separately. A leaf sample from single diploid Brassica oleracea was added to each sample to serve as an internal size standard (Arumuganathan \& Earle, 1991).

\section{Results}

\section{DNA sequence and haplotype analyses}

A $466 \mathrm{bp} \operatorname{trn} L$ region was sequenced and analysed from 245 individuals representing six Arabis species and Halimolobus perplexa (Tables 1 and 2; Fig. 1). All sequences have been deposited in GenBank (AF312971, AF312950-AF312963, AF312964-AF312970). Fifteen single nucleotide polymorphisms (SNPs), one 6-bp insertion-deletion polymorphism (indel) and a single region (position 207-211) in which five adjacent nucleotides differed between Arabis spp. and H. perplexa were

(c) The Genetics Society of Great Britain, Heredity, 87, 59-68. 
Table 1 Species and populations analysed ('see Fig. 1)

\begin{tabular}{|c|c|c|c|c|c|}
\hline Region $^{1}$ & Species & Locality & $N$ & Map number ${ }^{1}$ & $\operatorname{trn} L$ haplotype \\
\hline \multirow{19}{*}{ North } & \multirow{6}{*}{ Arabis drummondii } & Mt. Baker, WA & 1 & 1 & $\mathrm{~F}$ \\
\hline & & Challis, Lemhi Co, ID & 2 & 2 & $\mathrm{C}$ \\
\hline & & Absorka, MT & 1 & 4 & $\mathrm{D}$ \\
\hline & & Beaverhead Co, MT & 12 & 9 & $\mathrm{C}, \mathrm{D}, \mathrm{E}$ \\
\hline & & Pahsimeroi, Lemhi Co, ID & 1 & 21 & $\mathrm{C}$ \\
\hline & & Lemhi Co, ID & 2 & 24 & $\mathrm{D}, \mathrm{L}$ \\
\hline & \multirow{10}{*}{ A. holboellii } & Challis, Lemhi Co, ID & 21 & 2 & $\mathrm{C}, \mathrm{D}, \mathrm{I}, \mathrm{J}$ \\
\hline & & Wallowa Mtns, OR & 29 & 3 & $\mathrm{~K}$ \\
\hline & & Missoula MT & 18 & 5 & $\mathrm{I}, \mathrm{N}$ \\
\hline & & Ranch Creek, Granite Co, MT & 18 & 6 & $\mathrm{C}, \mathrm{D}, \mathrm{H}, \mathrm{I}, \mathrm{K}$ \\
\hline & & Highwood Mtns, MT & 15 & 7 & $\mathrm{I}, \mathrm{K}, \mathrm{N}$ \\
\hline & & Ravalli Co, MT & 47 & 8 & $\mathrm{~B}, \mathrm{I}, \mathrm{K}, \mathrm{L}, \mathrm{N}$ \\
\hline & & Beaverhead Co, MT & 19 & 9 & $\mathrm{C}, \mathrm{E}, \mathrm{K}, \mathrm{L}$ \\
\hline & & Deerlodge Co, MT & 2 & 10 & $\mathrm{C}$ \\
\hline & & Rogers Pass, MT & 3 & 27 & I \\
\hline & & Bandy Ranch, Missoula Co, MT & 30 & 32 & $\mathrm{~K}, \mathrm{~N}, \mathrm{P}$ \\
\hline & A. fecunda & Beaverhead Co, MT & 1 & 9 & I \\
\hline & A. lyallii & Idaho Co, ID & 1 & 26 & $\mathrm{C}$ \\
\hline & Halimolobus perplexa & Lemhi Co, ID & 1 & 24 & $\mathrm{R}$ \\
\hline \multirow[t]{10}{*}{ South-west } & \multirow[t]{2}{*}{ A. drummondii } & Cottonwood Pass, Inyo NF, CA & 1 & 11 & G \\
\hline & & Saddle Mtn, CA & 1 & 25 & $\mathrm{C}$ \\
\hline & \multirow[t]{8}{*}{ A. holboellii } & Cottonwood Pass, Inyo NF, CA & 1 & 11 & G \\
\hline & & Plumas Natl. Forest, CA & 2 & 12 & M \\
\hline & & Emerald Bay, Lake Tahoe, CA & 1 & 13 & M \\
\hline & & Ebbetts Pass, Toiyabe NF, CA & 1 & 14 & $\mathrm{~K}$ \\
\hline & & Echo Lake, El Dorado NF, CA & 1 & 15 & $\mathrm{C}$ \\
\hline & & Virginia City, Stoery Co, CA & 1 & 16 & $\mathrm{~L}$ \\
\hline & & Luther Pass, Eldorado NF, CA & 2 & 17 & $\mathrm{C}, \mathrm{M}$ \\
\hline & & Sonora Pass, Toiyabe NF, CA & 1 & 18 & $\mathrm{~L}$ \\
\hline \multirow[t]{6}{*}{ South-east } & \multirow[t]{4}{*}{ A. drummondii } & Dark Canyon, Grand Co, UT & 1 & 19 & $\mathrm{C}$ \\
\hline & & Cedar Breaks, Iron Co, UT & 1 & 20 & $\mathrm{D}$ \\
\hline & & Kaibab, AZ & 1 & 22 & $\mathrm{D}$ \\
\hline & & Wayne Co, UT & 1 & 31 & $\mathrm{~L}$ \\
\hline & A. beckwithii & Tooele Co, UT & 1 & 30 & I \\
\hline & A. fendleri & Gunnison Co., CO & 1 & 33 & $\mathrm{C}$ \\
\hline Michigan & A. drummondii & Saugatuck Dunes, MI & 1 & 28 & $\mathrm{D}$ \\
\hline Greenland & A. holboellii & Godhaun & 2 & 29 & $\mathrm{~N}$ \\
\hline
\end{tabular}

identified, and this translated into 16 different chloroplast haplotypes (Tables 2 and 3). Interestingly, trnL haplotype $\mathrm{C}$ was found in $A$. holboellii, A. drummondii, $A$. lyallii and $A$. fendleri, and haplotype I was found in A. holboellii, A. drummondii, A. fecunda and A. beckwithii (Tables 1 and 3).

Arabis holboellii and A. drummondii were characterized by 15 different haplotypes. Both species shared six haplotypes (C, D, E, G, I, L; Table 3), all of which occurred in both diploid and triploid individuals. Haplotype $\mathrm{F}$ occurred only in triploid A. drummondii, and haplotypes $\mathrm{J}, \mathrm{M}$ and $\mathrm{O}$ occurred only in triploid A. holboellii (Table 3).

\section{Ploidy distribution and karyotype variation}

Flow cytometric analysis of six species of Arabis detected comparable genome size values in the diploid $(2 \mathrm{C} \approx 0.35)$ and polyploid ranges $(3 \mathrm{C} \approx 0.55$ and $4 \mathrm{C} \approx 0.72$, Fig. 2). Both diploid and polyploid individuals of $A$. drummondii (2C, 3C and 4C) and $A$. holboellii (2C and 3C) were found (Fig. 2). Single samples of A. lyallii and $A$. fecunda were diploid, and only triploidy was observed in A. fendleri and A. beckwithii (Fig. 2).

The fluorescence values for 2C A. holboellii differed significantly from normality (Kolmogorov-Smirnov test for normality $=0.096$, d.f. $=185, P<0.001$ ), and

(c) The Genetics Society of Great Britain, Heredity, 87, 59-68. 

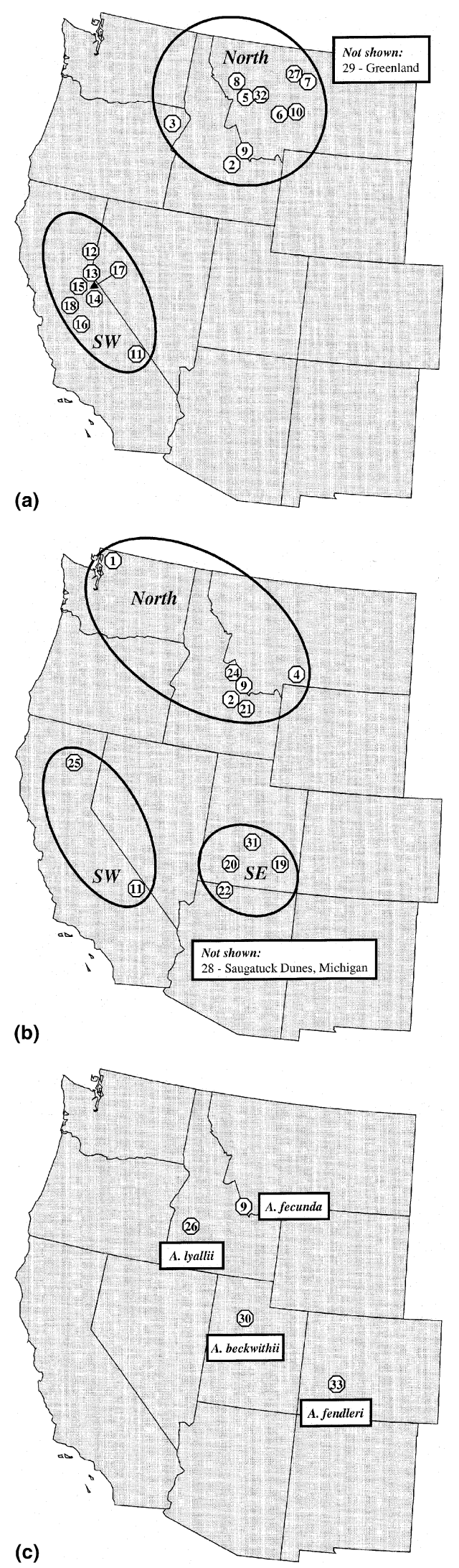

Fig. 1 Geographical distribution of (a) A. holboellii, (b) A. drummondii and (c) Arabis species analysed (numbers refer to Table 1).

appeared bimodal (Fig. 3). We therefore assumed a cutoff point of 0.380 fluorescence units between the lower and higher peaks in further statistical analysis. The $2 \mathrm{C}$ distribution for $A$. drummondii did not deviate from normality (nonsignificant Kolmogorov-Smirnov test for normality with Lilliefors Significance Correction). Interestingly, the lower outlier of the $2 \mathrm{C} \mathrm{A}$. drummondii distribution possessed haplotype $\mathrm{G}$, and had a fluorescence value similar to $A$. holboellii (Fig. 3). The only other $\mathrm{G}$ haplotype identified here was a triploid $A$. holboellii, and furthermore both $\mathrm{G}$ haplotypes are from the same location (Table 1). The removal of haplotype $G$ from the $A$. drummondii distribution had no effect on the significance tests for normality.

The distribution of diploidy and triploidy was not restricted to any specific chloroplast haplotype of A. holboellii or $A$. drummondii (Fig. 4). Both $2 \mathrm{C}$ and $3 \mathrm{C}$ individuals possessed haplotypes $\mathrm{C}, \mathrm{D}, \mathrm{E}$ and $\mathrm{L}$ in A. drummondii (including a single $4 \mathrm{x}$ individual of haplotype D), and haplotypes $\mathrm{C}, \mathrm{D}, \mathrm{I}, \mathrm{K}, \mathrm{L}$ and $\mathrm{N}$ in $A$. holboellii (Fig. 4). However, genome size distributions differed among haplotypes (Figs. 4 and 5). The distribution of $2 \mathrm{C}$ fluorescence values in haplotype I was bimodal, and neither peak differed from normality ( $N=42$, Shapiro-Wilk's $W$ nonsignificant). 2C individuals of haplotype $\mathrm{K}$ had a non-normal distribution (Kolmogorov-Smirnov test for normality with Lilliefors Significance Correction $=0.43$, d.f. $=70, \quad P=0.001$ ) which was skewed towards greater fluorescence values. Finally, the distribution of $2 \mathrm{C}$ individuals having haplotype $\mathrm{N}$ did not deviate from normality (ShapiroWilk's $W$ nonsignificant), although its mode was shifted towards the skewed region of haplotype K (Fig. 5).

\section{Phylogenetic analysis of ploidy variation}

The samples were divided into three geographical groups (Fig. 1). Haplotypes $\mathrm{C}$ and $\mathrm{L}$ were found in all three regions, and included both $2 \mathrm{C}$ and $3 \mathrm{C}$ individuals (Figs. 4 and 6). Haplotypes $\mathrm{G}$ and $\mathrm{M}$ were specific to the south-west, and included both $2 \mathrm{C}$ and $3 \mathrm{C}$ individuals (Figs. 4 and 6). Haplotypes B, E, F, H, J, and P were specific to the northern group and included $2 \mathrm{C}$ and $3 \mathrm{C}$ individuals (Fig. 4). No haplotypes were specific to the south-east group. Interestingly, haplotype $\mathrm{N}$ was found in samples from both Greenland and Montana (Table 1, Fig. 4).

We assumed that both the 6 bp indel and site with five adjacent SNPs were each the result of a single mutation

(c) The Genetics Society of Great Britain, Heredity, 87, 59-68. 


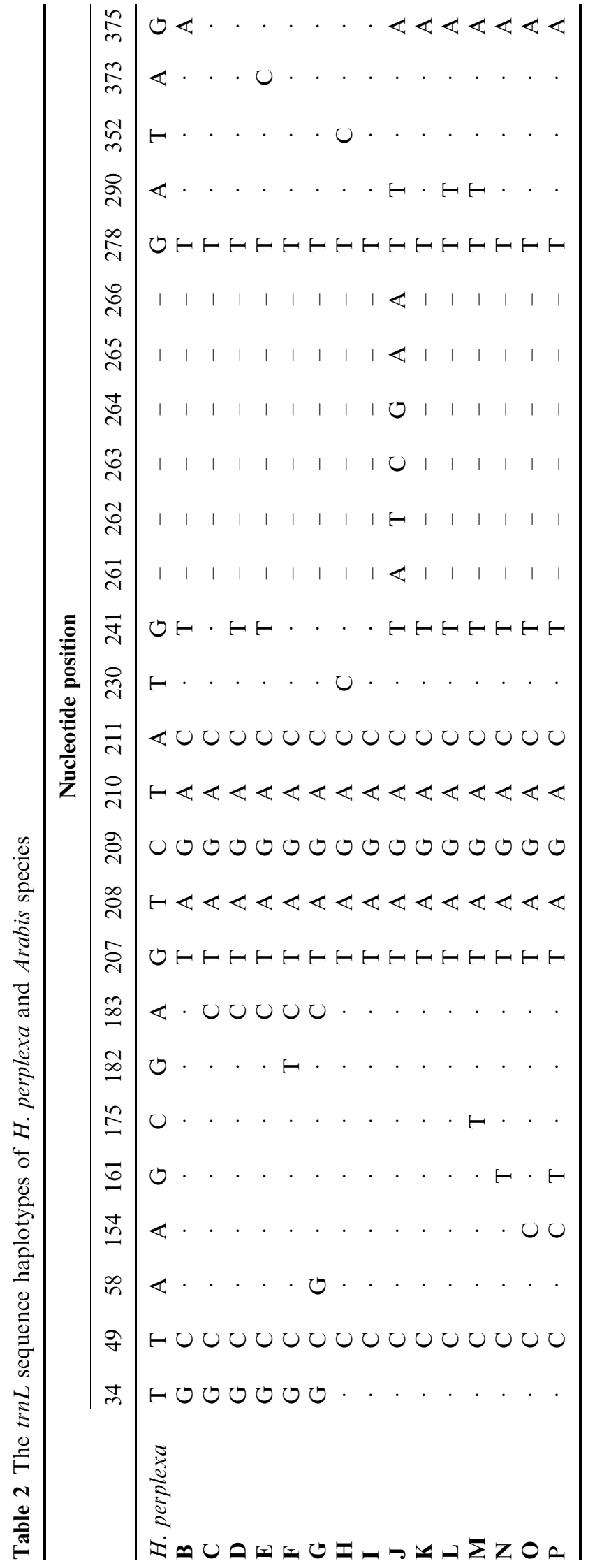

(c) The Genetics Society of Great Britain, Heredity, 87, 59-68. event, to yield 17 phylogenetically informative polymorphisms (Table 2). A phylogenetic analysis of the 15 Arabis haplotypes, using $H$. perplexa as an outgroup, showed little statistical support for any haplotype clade (Fig. 6). Haplotype diversity did not differ between samples grouped by species, region or ploidy (Table 4). Tajima's $D$-test statistics were nonsignificant for all

Table 3 Haplotype and ploidy (C) frequencies in Arabis holboellii and A. drummondii (frequencies were calculated within species)

\begin{tabular}{lcccccc}
\hline & \multicolumn{3}{c}{ A. drummondii } & & \multicolumn{2}{c}{ A. holboellii } \\
\cline { 2 - 3 } \cline { 6 - 7 } & $2 \mathrm{C}$ & $3 \mathrm{C}$ & $4 \mathrm{C}$ & & $2 \mathrm{C}$ & $3 \mathrm{C}$ \\
\hline $\mathrm{B}$ & - & - & - & & 0.005 & - \\
$\mathrm{C}$ & 0.379 & 0.103 & - & & 0.007 & 0.005 \\
$\mathrm{D}$ & 0.172 & 0.034 & 0.03 & & 0.005 & 0.023 \\
$\mathrm{E}$ & 0.069 & 0.034 & - & 0.014 & - \\
$\mathrm{F}$ & - & 0.034 & - & - & - \\
$\mathrm{G}$ & 0.034 & - & - & & - & 0.005 \\
$\mathrm{H}$ & - & - & - & & 0.005 & - \\
$\mathrm{I}$ & 0.034 & - & - & 0.198 & 0.081 \\
$\mathrm{~J}$ & - & - & - & & - & 0.023 \\
$\mathrm{~K}$ & - & - & - & 0.311 & 0.009 \\
$\mathrm{~L}$ & 0.034 & 0.034 & - & & 0.068 & 0.005 \\
$\mathrm{M}$ & - & - & - & & - & 0.018 \\
$\mathrm{~N}$ & - & - & - & 0.176 & 0.018 \\
$\mathrm{O}$ & - & - & - & - & 0.005 \\
$\mathrm{P}$ & - & - & - & 0.005 & - \\
\hline
\end{tabular}

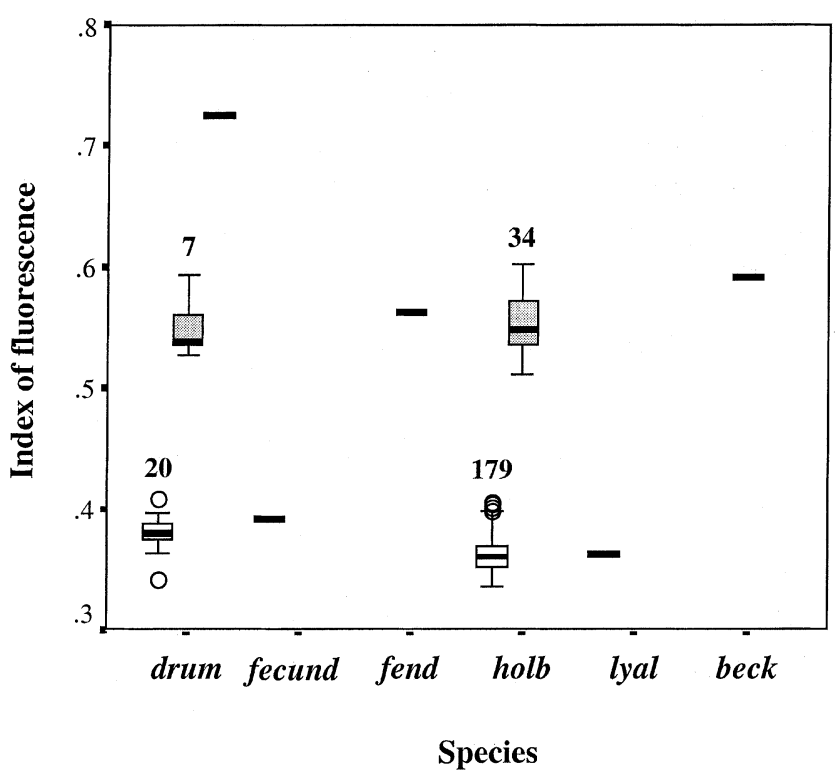

Fig. 2 Boxplots of ploidy analyses of different Arabis species (black numbers indicate sample sizes, bars with no numbers are based on a single individual, and circles represent outliers). Vertical axis represents index of fluorescence values obtained from flow cytometric analysis. 

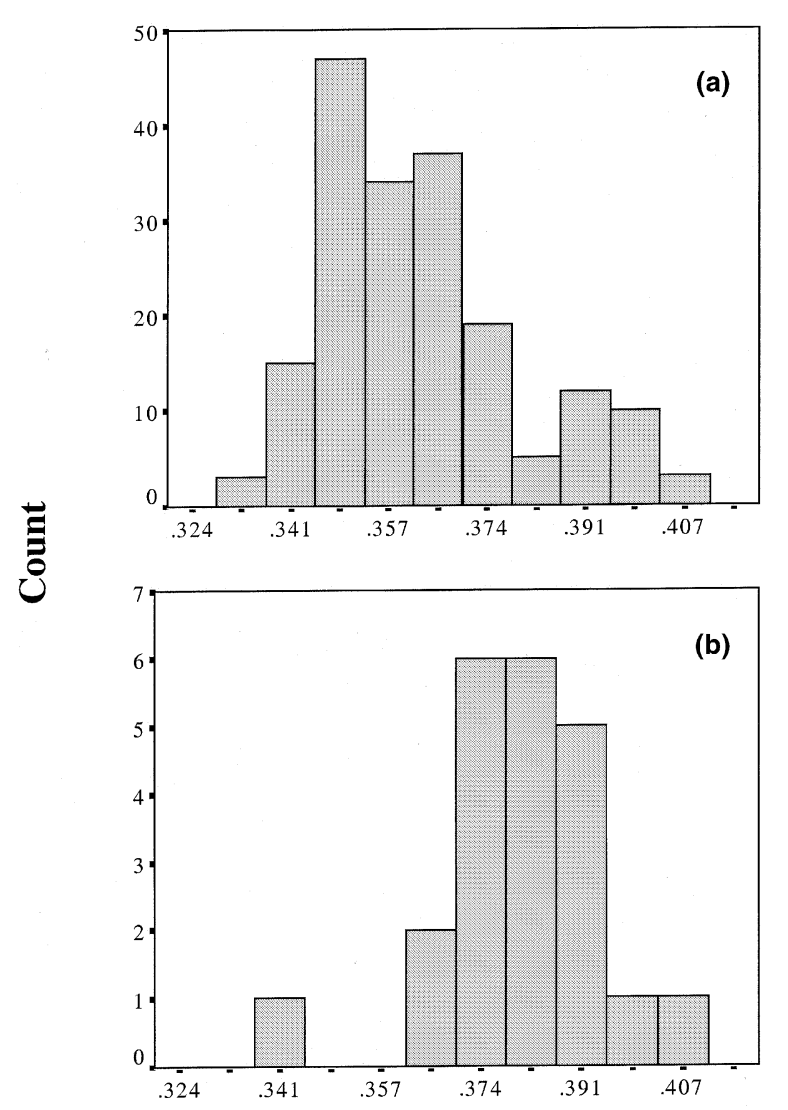

Index of fluorescence

Fig. 3 Distributions of (a) A. holboellii and (b) A. drummondii diploid fluorescence values.

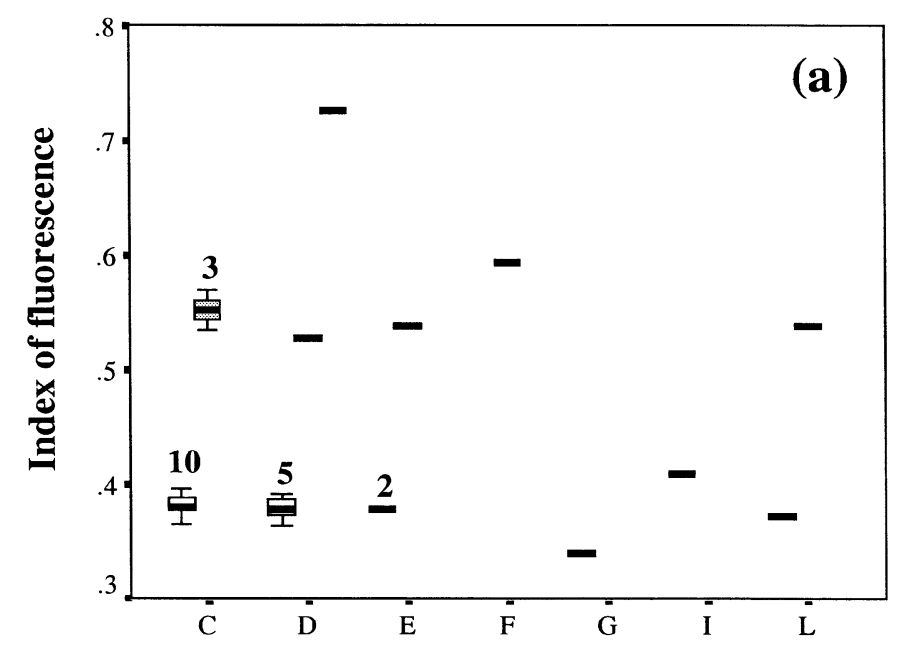

groups, and thus none of the polymorphisms deviated from selective neutrality (Table 4).

\section{Discussion}

\section{Recurrent origins of polyploidy}

Polyploid genotypes have arisen repeatedly within the Arabis holboellii complex. Of the seven A. drummondii and $14 \mathrm{~A}$. holboellii haplotypes identified from the chloroplast sequences, four and six (respectively) were characterized by both diploid and polyploid individuals (Figs. 4 and 6, Table 3). Furthermore, low levels of boostrap support for any haplotype clade (Fig. 6) demonstrates that a gene phylogeny cannot be well resolved with our data, and thus the propensity for generating polyploidy is shared between unrelated chloroplast lineages.

Because genome doubling (i.e. autopolyploidization) at the zygote stage cannot result in triploidy, what is the mode of polyploidization in this complex? A newly formed triploid lineage could be formed via two mechanisms, both of which entail the fertilization of an unreduced gamete by a reduced gamete. In the first case, the source of the unreduced gamete is a tetraploid individual which undergoes normal meiosis (Bell, 1982), but the extremely low frequency of tetraploid Arabis precludes this mechanism. A more likely scenario is the occasional production of unreduced gametes through environmental influence. For example, cold-shock has been implicated in polyploidization for a number of

\section{Chloroplast haplotype}

Fig. 4 Index of fluorescence distributions for (a) Arabis drummondii and (b) A. holboellii. Black numbers over boxplots indicate sample sizes, horizontal lines with no numbers represent single individuals, and white circles represent outliers. 

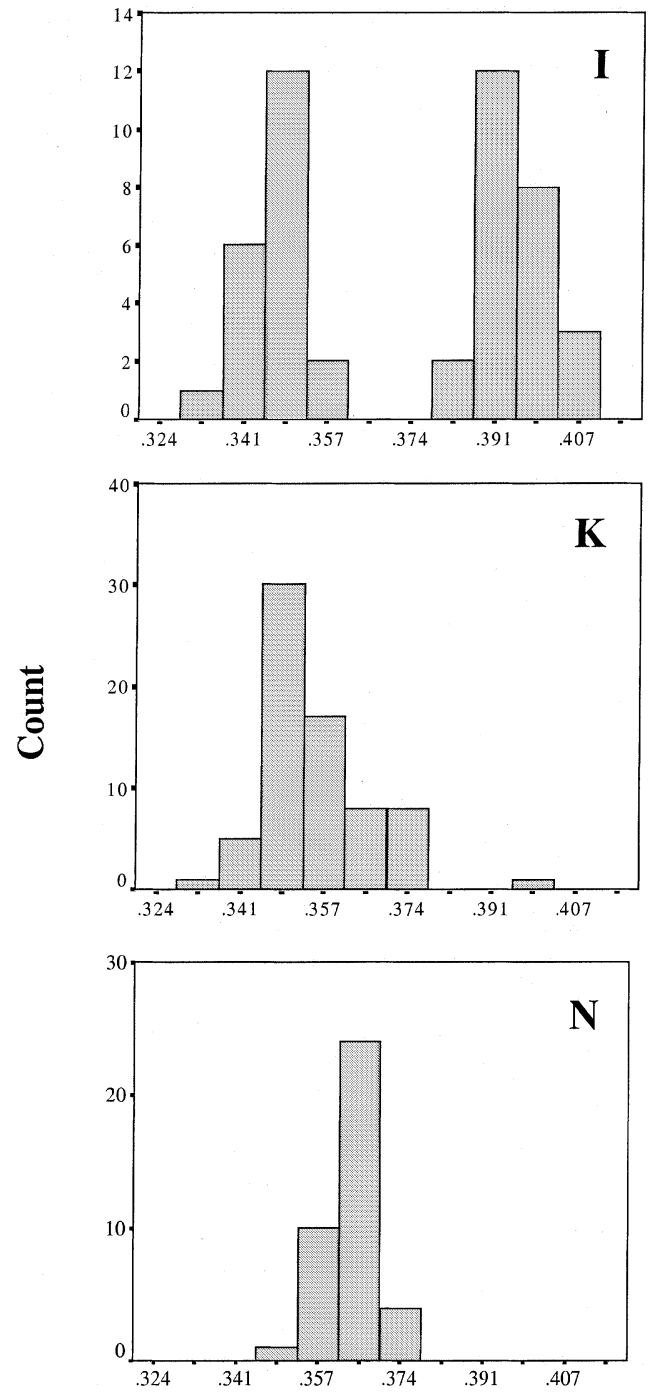

\section{Index of fluorescence}

Fig. 5 Index of fluorescence distributions for diploid individuals of haplotypes I, K and $\mathrm{N}(N=42,67,37$, respectively).

temperate taxa (Bretagnolle \& Thompson, 1995). The evolutionary first step towards the generation of triploidy thus requires no specific genetic mutation, although its stable transmission to offspring would not be possible unless some compensatory mutation enabled balanced chromosome segregation through meiosis (e.g. apomixis, although see Kadereit, 1991).

\section{Ploidy variation in the Arabis holboellii complex}

Polyploid angiosperms are typically even-ploid (Ramsey \& Schemske, 1998). In contrast, 3C (triploid) genotypes are prevalent throughout the samples in this study (Fig. 2). Triploid Arabis have previously been

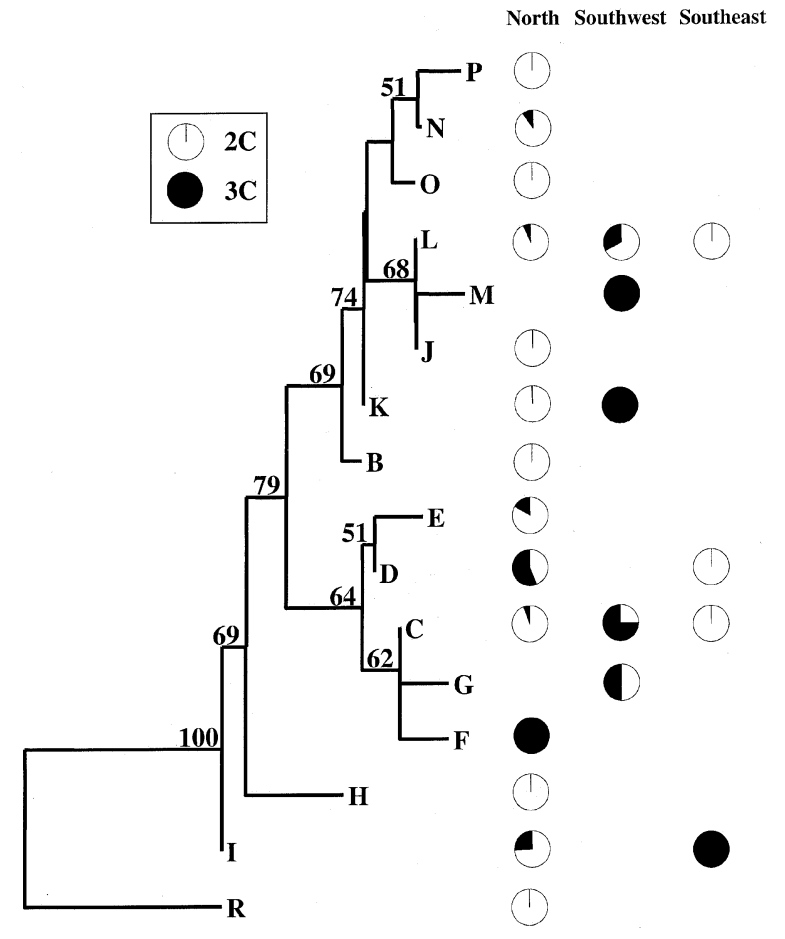

Fig. 6 Neighbour-joining tree calculated from trnL haplotypes, using (Jukes \& Cantor, 1969) correction. Bootstrap values (100 replicates) appear on all nodes, and pie charts represent proportions of ploidy types. Not shown are two diploid individuals from Godhaun (Greenland) having haplotype N, and a single tetraploid individual from Saugatuck Dunes (Michigan) having haplotype D. Outgroup $(\mathrm{R})$ is H. perplexa.

documented (Böcher, 1951; Mulligan, 1995), and hence it appears to be a common ploidy type within this group.

The genome size distribution for all diploid $A$. holboellii together was bimodal (Fig. 3). Karyological analyses of individuals sampled from the lower range showed them to have 14 chromosomes, and thus the lower peak represents true diploid A. holboellii. Arabis holboellii in the diploid range had significantly smaller genome sizes than corresponding 2C $A$. drummondii (Figs. 3-5, $T=-9.49, P<0.001, N=178$ ). Considering that both species have a haploid chromosome number, $n=7$ (Koch et al., 1999), genome size differences between them are likely attributable to noncoding DNA (e.g. heterochromatin).

Intraspecific variation in genome size was also detected within both diploid and triploid A. holboellii and A. drummondii (Figs. 3, 4, 5). The bimodal or skewed fluorescence distributions for $2 \mathrm{C}$ haplotypes I, $\mathrm{K}$ and $\mathrm{N}$ are suggestive of aneuploidy for one or two chromosomes, showing two different genome size increments, $\sim 28 \%$ (relative to haploid genome size) in haplotype

(C) The Genetics Society of Great Britain, Heredity, 87, 59-68. 
Table 4 Estimates of haplotype diversity $(H)$, Tajima's statistic $(D)$, and nucleotide diversity (ð) for subsamples of the dataset

\begin{tabular}{lrrrr}
\hline Population & $N$ & $H(\mathrm{SD})$ & \multicolumn{1}{c}{ Tajima's $D(P)$} & $\delta$ \\
\hline All & 245 & $0.812(0.012)$ & $0.0110(>0.10)$ & 0.0046 \\
A. holboellii (all) & 217 & $0.787(0.014)$ & $-0.0824(>0.10)$ & 0.0042 \\
A. holboellii (2x) & 184 & $0.762(0.016)$ & $0.0801(>0.10)$ & 0.0038 \\
A. holboellii (3x) & 33 & $0.820(0.048)$ & $0.5173(>0.10)$ & 0.0055 \\
A. drummondii (all) & 28 & $0.852(0.042)$ & $0.2274(>0.10)$ & 0.0053 \\
A. drummondii (2x) & 20 & $0.843(0.052)$ & $0.8840(>0.10)$ & 0.0054 \\
A. drummondii (3x) & 8 & $0.893(0.086)$ & $-0.8556(>0.10)$ & 0.0048 \\
2x (North and South) & 204 & $0.784(0.015)$ & $0.1142(>0.10)$ & 0.0042 \\
3x (North and South) & 41 & $0.859(0.033)$ & $0.3021(>0.10)$ & 0.0060 \\
North (2x + 3x) & 228 & $0.791(0.013)$ & $0.2072(>0.10)$ & 0.0043 \\
South (2x + 3x) & 17 & $0.846(0.050)$ & $1.9189(>0.05)$ & 0.0070 \\
North (2x) & 196 & $0.772(0.016)$ & $0.2131(>0.10)$ & 0.0041 \\
South (2x) & 8 & $0.857(0.102)$ & $0.6492(>0.10)$ & 0.0060 \\
North (3x) & 30 & $0.795(0.056)$ & $0.3725(>0.10)$ & 0.0054 \\
South (3x) & 11 & $0.800(0.100)$ & $1.6224(>0.10)$ & 0.0074 \\
\hline
\end{tabular}

I and $\sim 14 \%$ in haplotypes $\mathrm{K}$ and $\mathrm{N}$ (Figs 3, 4, 5). Univalent chromosomes, one small and one large, have previously been described from A. holboellii (Böcher, 1951; Roy, 1995), and this is consistent with the genome size variation documented here. Considering previous chromosome studies (Böcher, 1951) these data suggest that aneuploidy may be common (Fig. 4), a phenomenon which has furthermore been confirmed by karyological and microsatellite analyses (unpubl. data). An alternative explanation for variation in genome size could be intraspecific variation for heterochromatin concentration, although this is less consistent with our data and previous karyological studies of the complex.

\section{Population structure}

It is interesting that we have identified different Arabis species with the same chloroplast haplotype (Table 3); trnL haplotypes shared between species have also been described for Brassica (Lannér, 1998). Since reproductive isolation has not been tested among named Arabis taxa, one possible explanation may be gene flow between 'morphospecies', as has been suggested by Koch et al. (1999). Our data nonetheless demonstrate species-specific differences in genome size between A. holboellii and A. drummondii (see above), and thus there is some degree of genetic isolation between them which prevents genome homogenization through random mating (Price et al., 1983).

The extensive geographical distribution of haplotype $\mathrm{N}$ (i.e. in Greenland and Montana; Figs 1, 5 and 6) is noteworthy. Assuming that extant North American Arabis populations were established by post-Pleistocene migrants from the south (Pielou, 1991), the widespread distribution of haplotype $\mathrm{N}$ could have resulted from it being a highly successful (and old) colonization genotype. Alternatively, if one considers that haplotype $\mathrm{N}$ could have had a wide pre-Pleistocene distribution which encompassed Greenland and North America, then its present-day distribution could be the result of survival in multiple glacial refugia. For example, disjunct populations of $A$. holboellii have been described from the St. Lawrence River Valley in Québec (Böcher, 1951), which may have been a glacial refugium (Marie-Victorin \& Rolland-Germain, 1964). Considering the loose relationships between Brassicaceae species designations and chloroplast sequence variation (Lannér, 1998; Koch et al., 1999), more loci are needed in order to resolve the actual colonization scenario.

\section{Implications for apomixis evolution}

Triploids that stably produce triploid offspring and maintain meiosis can only do so via apomictic reproduction (Bell, 1982; Ramsey \& Schemske, 1998, but see Kadereit, 1991). Hence, the triploids in our sample analyses are likely to be apomictic (Böcher, 1951; Roy, 1995). Diploid apomixis has also been proposed in Arabis (Böcher, 1951; Roy, 1995), although we have insufficient information to determine the reproductive mode of the diploids analysed here. We suspect that diploid sexual A. holboellii do exist, as evidenced from our unpublished observations on endosperm production (e.g. $2 x$ individuals producing 3x endosperm, sensu Matzk et al., 2000). As these putative sexual individuals have identical haplotypes to triploids (i.e. apomicts), apomictic lineages may have originated repeatedly in Arabis species.

(c) The Genetics Society of Great Britain, Heredity, 87, 59-68. 
Providing an explanation for the origin of apomixis has proven difficult, as its evolution from a sexual ancestor (Beukeboom \& Vrijenhoek, 1998) is thought to entail simultaneous accumulation of at least two genetically unrelated mutations, leading to both unreduced egg production and parthenogenetic development (Bell, 1982; Mogie, 1992). The evolution of either one of these traits in the absence of the other decreases fitness, and thus envisioning two random mutations leading to balanced apomixis has been difficult (Mogie, 1992). One possible solution suggests the existence of a single 'apomixis factor' (Mogie, 1992), one which might be recessive and lethal in the diploid heterozygous and homozygous conditions, respectively, but which finds balanced expression and/or penetrance through dosage in the polyploid state. While this model is not widely applicable to the majority of apomictic plant taxa, which are tetraploid (Savidan, 2000), it may provide a working hypothesis to explain recurrent origins of apomixis in the A. holboellii complex.

If we make the parsimonious assumption that a genetic factor responsible for initiating apomixis evolved once during the evolution of Arabis, then widespread polymorphism throughout this group would imply a balance of advantages and disadvantages to its carriers. A recessive apomixis factor could in this way remain invisible to selection, unless occurring in the diploid homozygote condition (lethal) or in a balanced fashion with a dominant wild-type allele through polyploid dosage (e.g. Aaa apomict, sensu Mogie, 1992). Such a model of apomixis evolution is furthermore consistent with stable aneuploidy in $\mathrm{A}$. holboellii, as proper dosage of the 'apomixis' chromosome(s) alone could hypothetically lead to the apomictic phenotype. Finally, functional (although disturbed) microsporogenesis in apomictic individuals (Böcher, 1951) would enable low levels of gene flow back into sympatric sexual ancestors, thus assuring the repeated introgression of the recessive apomixis factor into sexual genetic backgrounds. Hybridization between reproductive biotypes could lead to fine-tuning of the 'apomixis factor' through recombination, and furthermore may enable this factor to purge itself of the deleterious mutations that are expected to accumulate in asexual lineages.

\section{Acknowledgements}

We would like to extend our gratitude to M.-L. Voigt, D. Schnabelrauch and A. Figuth for their help with sequencing, and to K. Krämer for his work with flow cytometry. Additional seeds were collected by J. Konovsky, M. Marler, B. Smith, S. Rhoades, and M. Windham. This work was supported by the
Max-Planck-Gesellschaft and by US National Science Foundation grant DEB-9527725 to TMO. TFS would finally like to thank warmly Andrea and Lara for their patience and care throughout this work.

\section{References}

ARUMUgANATHAN, K. AND EARLE, E. D. 1991. Estimation of nuclear DNA content of plants by flow cytometry. Plant Mol. Biol. Rep., 9, 229-233.

ASKer, S. AND Jerling, L. 1992. Apomixis in Plants. CRC Press, Boca Raton, FL.

BELL, G. 1982. The Masterpiece of Nature. University of California Press, Berkeley, CA.

BEUKEBOOM, L. W. AND VRIJENHOEK, R. C. 1998. Evolutionary genetics and ecology of sperm dependent parthenogenesis. J. Evol. Biol., 11, 755-782.

BEUKEBoOM, L. W., Ellers, J. AND VAN ALPHEN, J. J. M. 2000. Absence of single-locus complementary sex determination in the braconid wasps Asobara tabida and Alysia manducator. Heredity, 84, 29-36.

BÖCHER, T. W. 1951. Cytological and embryological studies in the amphi-apomictic Arabis holboellii complex. Kong. Danske Vidensk. Selsk., 6, 1-59.

BÖCHER, T. W. 1954. Experimental taxonomical studies in the Arabis holboellii complex. Svensk Bot. Tids., 48, 31-44.

BRETAGNOLLE, F. AND THOMPSON, J. D. 1995. Gametes with the somatic chromosome number: mechanisms of their formation and role in the evolution of autopolyploid plants. New Phytol., 129, 1-22.

CAMACHO, J. P. M., SHARBEL, T. F. AND BEUKEBOOM, L. W. 2000. B chromosome evolution. Phil. Trans. R. Soc. B, 355, 163-178.

CARMAN, J. G. 1997. Asynchronous expression of duplicate genes in angiosperms may cause apomixis, bispory, tetraspory, and polyembryony (review). Biol. J. Linn. Soc., 61, $51-94$.

DORN, R. D. 1984. Vascular Plants of Montana. Mountain West Publishing, Cheyenne, WY.

Felsenstein, J. 1989. PHYliP - Phylogeny Inference Package (Version 3.2). Cladistics, 5, 164-166.

JUKES, T. H. AND CANTOR, C. R. 1969. Evolution of protein molecules. In: Munro, H. H. (ed.) Mammalian Protein Metabolism, pp. 21-132. Academic Press, New York.

KADEREIT, J. W. 1991. A note on the genomic consequences of regular bivalent formation and continued fertility in triploids. Pl. Syst. Evol., 175, 93-99.

KOCH, M., BISHOP, J. AND MITCHELL-OLDS, T. 1999. Molecular systematics and evolution of Arabidopsis and Arabis. Plant Biol., 1, 529-537.

LANNÉR, C. 1998. Relationships of wild Brassica species with chromosome number $2 \mathrm{n}=18$, based on the comparison of the DNA sequence of the chloroplast intergenic region between $\operatorname{trn} L$ (UAA) and $\operatorname{trnF}$ (GAA). Can. J. Bot., 76, 228-237.

MARIE-VICTORIN, F. AND ROLLAND-GERMAIN, F. 1964. Flore de L'Anticosti-Minganie. Les Presses de l'Université de Montréal, Montréal.

(C) The Genetics Society of Great Britain, Heredity, 87, 59-68. 
MATZK, F., MEISTER, A. AND SCHUBERT, I. 2000. An efficient screen for reproductive pathways using mature seeds of monocots and dicots. The Plant J., 21, 97-108.

MichoD, R. E. 1995. Eros and Evolution. A Natural Philosophy of Sex. Addison-Wesley, Bonn.

MOGIE, M. 1986. On the relationship between asexual reproduction and polyploidy. J. Theor. Biol., 122, 493-498.

Mogie, M. 1992. The Evolution of Asexual Reproduction in Plants. Chapman \& Hall, London.

MULligan, G.A. 1995. Synopsis of the genus Arabis (Brassicaceae) in Canada, Alaska and Greenland. Rhodora, 97, 109-163.

MÜNTZING, A. 1936. The evolutionary significance of autopolyploidy. Hereditas, 21, 263-378.

NEI, M. 1987. Molecular Evolutionary Genetics. Columbia University Press, New York.

PIElOU, E. C. 1991. After the Ice Age. The Return of Life to Glaciated North America. The University of Chicago Press, London.

PRICE, H. J., CHAMBERS, K. L., BACHMANN, K. AND RIGGS, J. 1983. Inheritance of nuclear 2C DNA content variation in intraspecific and interspecific hybrids of Microseris (Asteraceae). Am. J. Bot., 70, 1133-1138.

RAMSEY, J. AND SCHEMSKE, D. W. 1998. Pathways, mechanisms, and rates of polyploid formation in flowering plants. Ann. Rev. Ecol. Syst., 29, 467-501.

Rollins, R. C. 1941. A monographic study of Arabis in western North America. Rhodora, 43, 289-325 348-411 425-481.
ROLLINS, R. C. 1981. Studies of Arabis (Cruciferae) of western North America. Syst. Bot., 6, 55-64.

ROY, B. A. 1993. Patterns of rust infection as a function of host genetic diversity and host density in natural populations of the apomictic crucifer, Arabis holboellii. Evolution, 47, $111-124$

ROY, B. A. 1995. The breeding systems of six species of Arabis (Brassicaceae). Am. J. Bot., 82, 869-877.

ROY, B. A. AND BIERZYCHUDEK, P. 1993. The potential for rust infection to cause natural selection in apomictic Arabis holboellii (Brassicaceae). Oecologia, 95, 533-541.

ROY, B. A. AND RIESEBERG, L. H. 1989. Evidence for apomixis in Arabis. J. Hered., 80, 506-508.

ROZAS, J. AND ROZAS, R. 1999. DNASP, Version 3: an integrated program for molecular population genetics and molecular evolution analysis. Bioinformatics, 15, 174-175.

SAVIDAN, Y. 2000. Apomixis: genetics and breeding. Pl. Breed. Rev., 18, 13-86.

suomalainen, E. 1950. Parthenogenesis in animals. $A d v$. Genet., 3, 193-253.

TAJIMA, F. 1989. Statistical method for testing the neutral mutation hypothesis by DNA polymorphism. Genetics, $\mathbf{1 2 3}$, 585-595.

VAN DE PEER, Y. AND DE WACHTER, R. 1994. TREECON for Windows: a software package for the construction and drawing of evolutionary trees for the Microsoft Windows environment. Comp. Appl. Biosci., 10, 569-570. 